\title{
Inuit Food Insecurity as a Consequence of Fragmented Marine Resource Management Policies? Emerging Lessons from Nunatsiavut
}

\author{
Melina Kourantidou, ${ }^{1,2}$ Porter Hoagland ${ }^{1}$ and Megan Bailey ${ }^{3}$
}

(Received 1 October 2020; accepted in revised form 29 September 2021)

\begin{abstract}
Historically, Inuit communities of the Arctic have relied significantly on the living marine resources of their coastal waters for nutrition, underpinning community cohesion and enhancing individual and collective well-being. Inadequate understanding of the conditions of coastal marine stocks and their dynamics, along with failed past fisheries management practices, now threatens secure access to these resources for food and nutrition. We examine the degree of integration of modern Canadian federal food and marine resource management policies, which heretofore have been unable to lessen food insecurity in the Arctic, suggesting that causes rather than symptoms need to be treated. Using evidence from Nunatsiavut, northern Labrador, we assess the limits to marine resource governance affecting access to traditionally important food sources. We explore the potential for both increased subsistence harvests and enhanced access to commercial fisheries in mitigating Inuit food insecurity, arguing for the relevance of expanded marine resource assessments, more focused fisheries management, and integration with policies designed to mitigate food insecurity. Crucially, the absence of methods for tracking changes in locally harvested marine resources threatens not only individual and household nutrition but also the social, economic, and cultural integrity of Inuit communities. We further describe the needs for monitoring and propose the use of indicators that capture the contributions of locally harvested marine resources to increased food security along with a framework that allows for utilizing local knowledge and observations. Relying on emerging lessons from research in Nunatsiavut, we build a foundation for a better understanding of both the political and institutional legacies that contribute to Labrador Inuit food insecurity and discuss how the deeper integration of food and marine resource management policies could help mitigate it.
\end{abstract}

Key words: food insecurity; food sovereignty; Labrador Inuit; Arctic; traditional ecological knowledge; Western science observations; monitoring; Nunatsiavut; marine resource management; governance

RÉSUMÉ. Au fil de l'histoire, les communautés inuites de l'Arctique ont dépendu à grande échelle des ressources marines vivantes de leurs eaux côtières pour leurs besoins alimentaires, pour soutenir la cohésion des communautés et pour rehausser le bien-être individuel et collectif. La compréhension inadéquate des conditions relatives aux stocks marins côtiers et à leur dynamique ainsi que les échecs ayant caractérisé les anciennes méthodes de gestion des pêches menacent maintenant l'accès sécuritaire à ces ressources à des fins d'alimentation et de nutrition. Nous nous penchons sur le degré d'intégration des politiques fédérales contemporaines de gestion des ressources marines et alimentaires au Canada qui, jusqu'à maintenant, n'ont pas réussi à amenuiser l'insécurité alimentaire dans l'Arctique, ce qui suggère qu'il faut plutôt traiter les causes que les symptômes. En nous appuyant sur des données émanant du Nunatsiavut, dans le nord du Labrador, nous évaluons les limites en matière de gouvernance des ressources marines qui ont des incidences sur l'accès aux sources de nourriture importantes qui revêtent une importance traditionnelle. Nous explorons les possibilités d'intensification des récoltes de subsistance et d'amélioration de l'accès aux pêcheries commerciales pour atténuer l'insécurité alimentaire chez les Inuits, et nous argumentons en faveur de la pertinence d'évaluations plus poussées des ressources marines, d'une gestion plus concentrée des pêches et de l'intégration avec des politiques conçues pour diminuer l'insécurité alimentaire. Fait important, l'absence de méthodes pour tenir compte des changements en matière de ressources marines récoltées à l'échelle locale menace non seulement l'alimentation des personnes et des ménages, mais également l'intégrité sociale, économique et culturelle des communautés inuites. Par ailleurs, nous décrivons les besoins en surveillance et proposons l'utilisation d'indicateurs qui tiennent compte de l'apport des ressources marines récoltées à l'échelle locale en vue de rehausser la sécurité alimentaire et d'un cadre de référence permettant le recours aux connaissances et aux observations locales. En nous appuyant sur les leçons émanant de la recherche du Nunatsiavut, nous établissons un fondement permettant de mieux comprendre les legs politiques et institutionnels qui jouent un rôle dans l'insécurité alimentaire au Labrador et nous discutons de la manière dont l'intégration plus approfondie des politiques de gestion des ressources marines et alimentaires serait susceptible d'aider à atténuer cette insécurité alimentaire.

\footnotetext{
${ }^{1}$ Woods Hole Oceanographic Institution, Marine Policy Center, 266 Woods Hole Road, MS\#41, Woods Hole, Massachusetts 02543, USA

${ }^{2}$ Corresponding author; mkourantidou@whoi.edu

${ }^{3}$ Marine Affairs Program, Dalhousie University, Life Sciences Centre, 1355 Oxford Street, PO Box 15000, Halifax, Nova Scotia, B3H 4R2 Canada

(C) The Arctic Institute of North America
} 
Mots clés : insécurité alimentaire; souveraineté alimentaire; Inuits du Labrador; Arctique; connaissances écologiques traditionnelles; observations scientifiques occidentales; surveillance; Nunatsiavut; gestion des ressources marines; gouvernance

Traduit pour la revue Arctic par Nicole Giguère.

\section{INTRODUCTION}

Access to food, especially for remote and geographically challenged parts of the world, is a primary concern that merits careful consideration in policy planning. In Canada, food insecurity manifests disproportionately in Atlantic Canada and across northern Canada. Among Inuit in the Arctic, food insecurity has been ubiquitous and worsening (Ford, 2009; Huet et al., 2012). The vulnerability of Arctic communities to this problem is the consequence of multiple factors that range from shifting climatic conditions and inadequate transportation infrastructure networks, dispossession of land and customary ways of living, to low socioeconomic standing and lack of access to resources (Ford, 2009; Beaumier and Ford, 2010; Huet et al., 2012; Orttung, 2019).

Regarding access to natural resources, harvesting of marine resources remains a critical necessity across Inuit Nunangat (the collective historic Inuit homelands located in what is now Canada). Access both to harvests and to markets for harvested products results in food, employment, and income, and supports cultural practices, health, and knowledge transfers (Knopp et al., 2012; Hoover et al., 2013; Durkalec et al., 2015).

While Canada's food and health policies acknowledge that many historical, economic, political, and social factors are important determinants of Inuit health (Agriculture and Agri-Food Canada, 2019), there remains a disconnect between this acknowledgment and the guidance provided for encompassing these determinants into policymaking. Token mentions of these determinants are not tied strongly to policies designed to mitigate food insecurity. Despite recognizing the need for approaching the problem holistically (Health Canada, 2019), Canada's new Food Guide and other regional and federal food policies that address food insecurity issues in the North fail to account for the important dimensions of food sovereignty that relate to self-sufficiency, the capacity to harvest, the need for access to harvesting grounds, and stable supply sources. Further, these policies, despite recognizing the existence of socioeconomic inequalities, fail to acknowledge that these inequalities are not only a barrier to accessing food sources, but also the outcome of inadequate resource policies that do not address access and equity in resource management (Kourantidou et al., 2020; Hoover et al., in press). These failings are particularly relevant in fisheries management, where a critical need for access to fish and fishing opportunities is currently unsupported by federal policy.

The concept of food sovereignty emerged in the mid1990 s, redefining food security to encompass also the means for food acquisition, besides just food supply. The capacity for food acquisition ultimately implies the potential for community and individual control and selfdetermination (Hoover, 2017).

The Food and Agriculture Organization of the United Nations (FAO, 1996, 2001) defines food security as "[A] situation that exists when all people, at all times, have physical, social and economic access to sufficient, safe and nutritious food that meets their dietary needs and food preferences for an active and healthy life...." The FAO's definition places more emphasis on adequacy of food and food production maximization than on food procurement, including in the latter the capacity to access natural resources. Thus, the FAO stance echoes the policy guidance embodied in the Canadian Food Guide and other federal mandates.

The high food security risk areas of the Arctic and Atlantic Canada collide in Nunatsiavut, northern Labrador, a self-governance region established in 2005 through the Labrador Inuit Land Claims Agreement (LILCA) (CIRNAC, 2005). The self-governance regime provides access rights to natural resources as well as the right of the Nunatsiavut Government to decide how resources in their lands and waters should be managed and developed.

Drawing on focus group discussions with 19 community members in Nain (August 2019) and Makkovik (November 2019), two of Nunatsiavut's five coastal communities, and semi-structured interviews with nine local and regional rightsholders and stakeholders (involved in the local commercial fishing and processing industry, the local co-management board and Fisheries and Oceans Canada [DFO]), this paper identifies marine resource management challenges related to food security in Nunatsiavut. Recognizing that marine resources are critical to nutrition and food security and an important part of the wage and subsistence economy among Labrador Inuit, we characterize the dimensions of marine resource governance that are important for safeguarding food security while also strengthening Inuit self-determination. Furthermore, we propose the development and application of indicators as a monitoring tool to help diversify risks, enhance food sovereignty, and contribute to sustainability of fish stocks and marine mammals, thereby ultimately improving food security for Labrador Inuit.

\section{THE IMPORTANCE OF MARINE RESOURCE MANAGEMENT IN FOOD SECURITY}

The challenge of mitigating food insecurity in Inuit Nunangat is a well-recognized one; food insecurity 
among households in northern Labrador has been found to be "over four times the level reported for the province of Newfoundland and Labrador in 2012 and five times the level of food insecurity measured for households in Canada in 2014" (Nunatsiavut Government, 2017a).

Because none of its five communities are accessible by road, the geographic remoteness of Nunatsiavut households limits access to affordable nutritious food. Instead, residents are highly dependent on store-bought foods delivered by sea or by air, with unpredictable weather conditions driving costs up and quality down (Goldhar et al., 2012; Aningmiuq and Sarazin, 2018).

In what follows we explore the potential for both subsistence marine resource harvesting and commercial fishing to mitigate food insecurity in Nunatsiavut. We highlight important dimensions of marine resource management that impact food security, and we argue for an integrated policy framework that cuts across public health, nutritional and dietary needs, economic development, and the management of marine resources.

\section{Subsistence Marine Resource Harvesting}

To the authors' knowledge, no studies to date have sought to examine the relationship between marine resource harvesting and food insecurity in Nunatsiavut. Despite the fact that Nunatsiavut communities have over the years diversified their economies in ways that allow them to engage in the broader wage-based economy, subsistence harvesting is still a fundamental direct and indirect contributor to their economies. Food security surveys in Canada have relied traditionally upon measures of food affordability and largely ignore the harvesting of country food for subsistence (Lysenko and Schott, 2019).

To date, much of the food insecurity research concerning the northern regions has focused on the intersection between food webs and human health, that is, whether traditionally harvested resources are safe to eat (Muir et al., 2005; Donaldson et al., 2013; Laird et al., 2013). More recently, the effects of climate change, such as shifting sea ice conditions and variations in snow packs, on traditional subsistence harvesting activities have also attracted significant research attention (Pearce et al., 2015; Huntington et al., 2016, 2017). However, the central role of resource management in providing access to country food and its links to socioeconomic and social-ecological dynamics has not received adequate attention.

Like all communities across Inuit Nunangat, communities along the north coast of Labrador have experienced fundamental changes to their connection with the land and their capacities to access and harvest traditional country food. Many of these changes have been attributed to past colonial practices such as forced shifts from nomadic to sedentary lifestyles, including required attendance at residential schools. These legacies of colonialism have severed connections to traditional hunting and fishing lands, limiting access to nutritious country food, and shifting diets to processed foods (Searles, 2002; Organ et al., 2014; Burnett et al., 2016). The costs of processed food due to the geographical isolation of the region are only one part of the problem for the food insecurity rates Nunatsiavut is experiencing. Federal mismanagement of species (e.g., Atlantic cod, Gadus morhua) and species' decline (Atlantic salmon, Salmo salar) has further limited harvesting and food procurement opportunities. Notably, limits to participation in harvesting represent not only a loss of food production but also lost opportunities for intergenerational knowledge transfer, specifically the transfer of Inuit traditional ecological knowledge (TEK) (Casimirri, 2003; Laugrand and Oosten, 2009; Kourantidou et al., 2020).

The importance of TEK to marine resource management has long been recognized in Indigenous community contexts (Huntington et al., 2002; Brook et al., 2009; Kaiser et al., 2019; Chapman and Schott, 2020; Cooke et al., 2021). Across Inuit Nunangat, there are successful examples that provide strong evidence for TEK knowledge holders' holistic understanding of how food security is enhanced by local marine biodiversity and ecological dynamics (BretonHoneyman et al., 2016; Ostertag et al., 2018). However, the inclusion of TEK in the design of marine resource management policies remains largely elusive. Although recognized in agreements or treaties with Indigenous peoples, and despite significant progress over recent years in integration in marine management (Loseto et al., 2018; Ostertag et al., 2018; MacMillan et al., 2019; Kourantidou et al., 2020; Zurba et al., 2021), TEK in several cases continues to be viewed as a form of subjugated knowledge and continues to be treated as marginal to Western ontologies (Kourantidou et al., 2020).

In Nunatsiavut, specific language in the LILCA (Ch. 12.4.7, 13.3.6) requires that harvest levels should be determined using any data compiled on an ongoing basis, including Inuit traditional knowledge. Under the LILCA, Labrador Inuit have established subsistence rights for local marine resources, with the Nunatsiavut Government assuming responsibility for Inuit harvesting within the Labrador Inuit Settlement Area.

However, reflecting on research conducted in the area over the past decades and also upon the truism that Canadian federal research priorities are largely determined primarily by the federal government itself with limited input from Nunatsiavut communities (Kourantidou et al., 2020, 2021), the subsistence economy and its connection to food security are largely understudied. Besides misguided research priorities often determined outside the communities, the coverage of questions and knowledge gaps of ongoing and recent research projects in many cases fails to reflect the concerns of community members directly or indirectly involved in subsistence harvesting.

The Arctic charr (Salvelinus alpinus), for example, is an iconic species, rich in protein and omega-3 fatty acids, which has been fished for more than a century and a half in Nunatsiavut (Dempson, 2008) and continues to be 
fished for both subsistence and commercial purposes. Data scarcity and fundamental knowledge gaps on ecological and biological characteristics of Arctic charr stocks, along with poor and outdated management of the commercial fishery over the past three decades, constrain the ability to understand how current levels of harvesting could impact harvest opportunities in the future (Kourantidou et al., 2022). The lack of monitoring in subsistence fishing, which seems to be a concern among people in Nunatsiavut, climate change uncertainties, and the difficulties and high enforcement costs for illegal fishing practices (including harvesting by non-locals) (Goldhar et al., 2012) exacerbate Inuit concerns about whether Arctic charr can continue to be a dietary staple. There are similar concerns for the health of stocks of other marine resources harvested for subsistence purposes in Nunatsiavut such as ringed seal and salmon (Goldhar et al., 2012), both very important food sources for Labrador Inuit.

Social-ecological dynamics and their influence on access and availability to country food also deserve more research attention. Substitution among country food sources for example is a major concern; when stocks are low for one subsistence species, harvesting pressure may increase for other subsistence species in order to supply needed calories and nutrients. The caribou, which has been a major food source in the Labrador Inuit diet (Wilson et al., 2014; Couturier et al., 2015; Kenny, 2017), provides a concrete example of the importance of such social-ecological dynamics. In recent years, caribou stocks in northern Labrador have declined significantly (Wilson et al., 2014; Couturier et al., 2015; COSEWIC, 2017), and substitution away from caribou may be leading to increased harvesting pressure on Arctic charr. Both caribou and Arctic charr are traditionally very important food sources. Further, moratoria on harvests of salmon and cod imposed by the federal government in 1998 and 1992, respectively (Schrank and Roy, 2013; DFO, 2020) and caribou (most recently issued by the Government of Newfoundland and Labrador in 2013; see also Borish et al., 2021), in combination with the collapse of the seal market triggered by anti-sealing campaigns and protests on the commercial seal hunt off the coast of Newfoundland and Labrador in the 1960s (Wenzel, $1978,1985)$ were all reasons that focus group and interview participants indicated had led to increased pressure on any country food options that remained available.

These social-ecological dynamics are complex and incompletely explored. No single driver likely prevails for the choices made in subsistence harvesting, but in the presence of shifting ecological conditions, monitoring these dynamics over time can help reveal some of the factors that drive food insecurity in the region. In order to develop a more comprehensive picture of the subsistence economy, further research efforts across both natural and social sciences are needed to address how shifts in social-ecological systems influence subsistence marine resource harvesting, while local knowledge needs to be better accounted for in management design. This requires improved communication corridors across disciplines and knowledge systems. The former can be achieved through increased attention to and investments in understanding the social science dimensions of the fisheries, particularly resource economics, since DFO, the key management authority heavily relies on natural sciences alone. The latter requires understanding and bridging the divide between Western science and Inuit knowledge systems.

As explained earlier, despite difficulties as well as past and ongoing failures to successfully bridge those knowledge systems, there have also been successes and advances in inclusion of local knowledge in marine design and management, often through co-management processes that bring together and enable building trust between the local governments representing the communities and provincial and federal management authorities. Therefore, in pursuing this goal it is key to strengthen these co-management processes while at the same time push for changes in traditional academic systems (i.e., institutions and funding mechanisms) that do not promote or reward time and effort spent in engaging with Indigenous communities.

Accessibility issues are increasing the risks of food insecurity (Wesche and Chan, 2010; Fergurson, 2011; Allard and Lemay, 2012; Goldhar et al., 2012; Nunavut Food Security Coalition, 2014; ITK, 2017; Kourantidou et al., 2021). Questions relating to the ability of the Labrador Inuit to access harvesting grounds have not been addressed adequately. Accessibility is a significant concern, especially for community members who may not have the financial capacity or the technical means to go fishing or hunting or whose opportunities to be on the land are challenged by climate change. The lack of access to fishing or harvesting grounds may lead to a gradual decline in TEK, undermining Labrador Inuit cultural values such as knowledge sharing and causing an increase in substitution of country foods with processed store-bought foods.

\section{Commercial Fishing}

Commercial fishing is an important source of income, contributing to employment opportunities in the pre- and post-harvesting sectors, which are the largest seasonal employment sectors in northern Labrador (ATN, 2018; Kourantidou et al., 2021). A large proportion of fisheries operations is run by the Torngat Fish Producers Co-Operative, an Indigenous cooperative formed in the early 1970s and owned by harvesters and plant employees. The Co-operative holds commercial fishing licenses and operates fish plants in Nain (processing Arctic charr and intermittently Icelandic scallop, Chlamys islandica) and in Makkovik (processing snow crab, Chionoecetes opilio, and turbot/Greenland halibut, Reinhardtius hippoglossoides).

In addition to the benefits of financial returns from commercial fisheries, Labrador Inuit also benefit from the maintenance of strong social and cultural bonds related to fishing. These bonds have roots that reach back centuries, and they remain strong despite shifts in the relevant target 

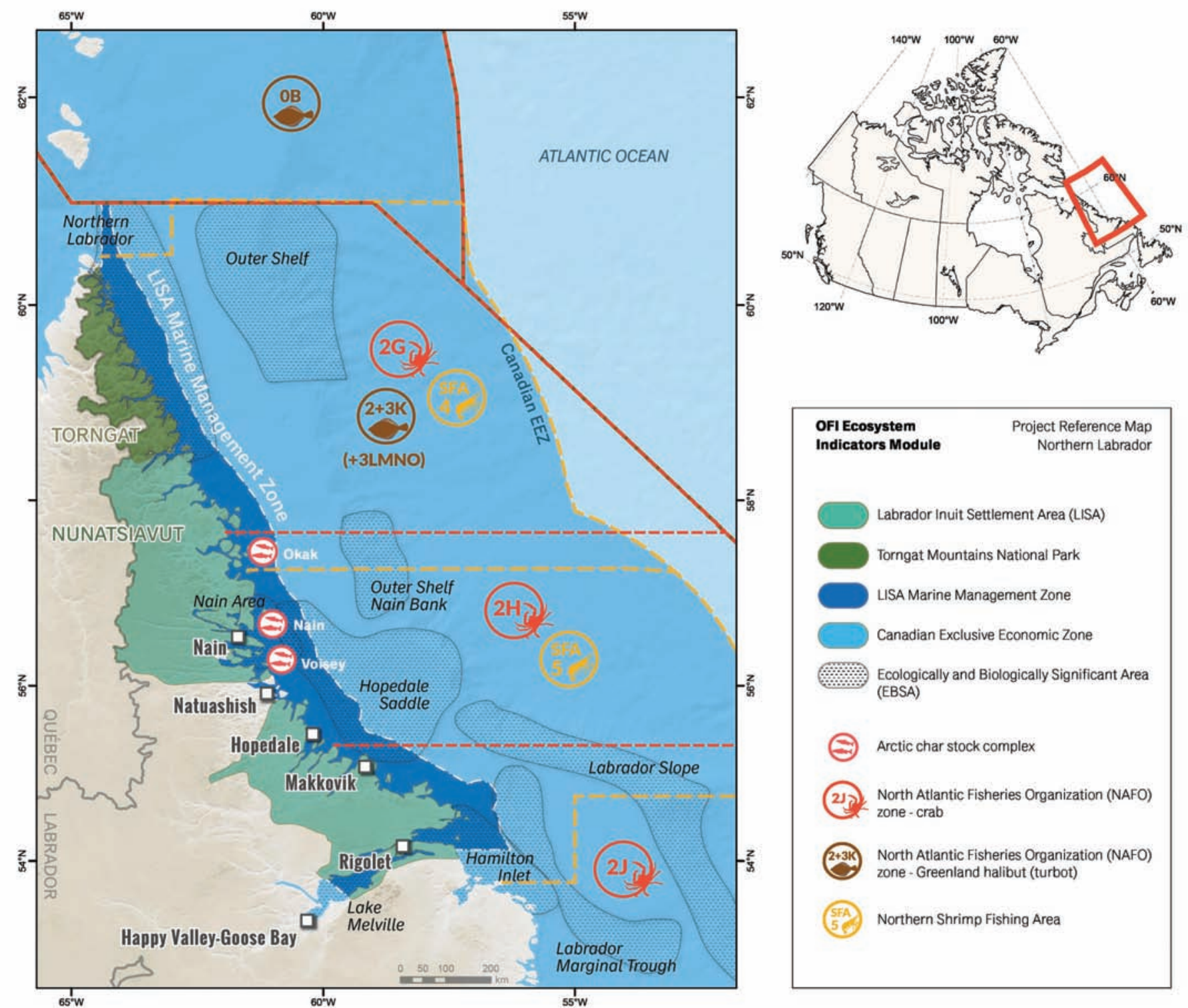

Labrador Inuit Settlement Area (LISA)

Torngat Mountains National Park

LSA Marine Management Zone

Canadian Exclusive Economic Zone

Ecologically and Biologically Significant Area (EBSA)

Arctic char stock complex

North Atlantic Fisheries Organization (NAFO) zone - crab

North Atlantic Fisheries Organization (NAFO) zone-Greenland halibut (turbot)

Northern Shrimp Fishing Area

FIG. 1. Key commercial fish species in Nunatsiavut and fishery management areas.

species (e.g., from cod and salmon fisheries to seals that stopped being harvested for commercial purposes to new fisheries emerging in the region such as the snow crab, turbot, and northern shrimp). Whether directly involved in fishing or in subsequent processing, Nunatsiavut Inuit derive very significant non-market economic benefits from fish harvesting. Examples of such prominent values identified in our focus groups include bequest value (the value placed on the option to use the fish in the future or the possibility of future generations to fish) and existence value (the right of or non-use value of existence of the fish in the future).

The political transition to Inuit self-governance came after more than 30 years of negotiations between the Labrador Inuit Association and the provincial and federal governments. Self-governance is the result of the Inuit's vote to accept the LILCA. The LILCA defines the Labrador
Inuit Settlement Area, the "Zone" and "Waters Adjacent to the Zone," the latter of which refers to Canadian fisheries waters within the portions of Northwest Atlantic Fisheries Organization Divisions $2 \mathrm{G}, 2 \mathrm{H}$, and $2 \mathrm{~J}$ that adjoin and lie due eastward of the Zone (Fig. 1). Further, it establishes access rights for Inuit and describes the conditions for commercial fishing (CIRNAC, 2005: Chapter 13). In Nunatsiavut, the LILCA also formalized integration among the federal, provincial, and Inuit government authorities for the management of commercial fisheries. This co-management occurs through the Torngat Joint Fisheries Board (TJFB), a tripartite, co-management advisory board, which provides recommendations to the federal Minister of Fisheries on fish stock management and conservation, among other things.

Notwithstanding the LILCA provisions relating to co-management, decision making still allows for 
federal ministerial discretion over fisheries management regulations (Snook et al., 2019a). Additionally, respondents noted that fishery management decisions are driven by objectives in Ottawa that can differ significantly from the socioeconomic objectives of the Nunatsiavut communities. The extent to which Labrador Inuit communities have achieved control over their fisheries to address food security issues therefore remains limited, owing to restrictions on full sovereignty with respect to marine resources adjacent to the Zone.

Some fisheries that were previously the cornerstone of the regional economy have experienced significant declines in production in recent years (e.g., Arctic charr) or have ceased completely due to stock depletion (e.g., Atlantic salmon and Atlantic cod). Harvesting and processing operations that were once sustaining communities along the coast of northern Labrador have declined significantly due to shifts in market conditions. Further, severe cutbacks in fisheries science (e.g., as in the case of Arctic charr) as a result of the implementation of top-down research priorities within the federal government have also likely contributed to the downsizing of commercial operations (Kourantidou et al., 2022). At the same time though, there exist aspirations to develop underutilized and exploratory fisheries such as the Icelandic scallop, whelk, and stripped shrimp fisheries.

The fishery for Arctic charr traditionally has been very important to Nunatsiavut Inuit, who have benefited culturally, socially, and economically from charr yields for more than 150 years (first commercial fishery in the 1860s) (Coady and Best, 1976). Indeed, the commercial charr fishery traditionally comprised a summer-long exodus from Nain, involving whole families heading out to fish at camps located several hours away, often for both charr and Atlantic salmon (CBC, 1973). Carrier vessels would collect harvested charr along the coast and deliver the catches to the processing plant in Nain. Today, the few remaining commercial charr fishers take only day trips out of Nain Bay, while commercial salmon fisheries have completely ceased. For example, only a handful of commercial fishers participated in the Arctic charr fishery in Nain in 2019 (versus 75-100 during the 1970s and 1980s), and the local processing plant was able to operate for only a few weeks that year. Interviews and consultations with key regional stakeholders such as the Torngat Co-Operative, which runs the fishery and processing, and the Torgnat Secretariat, the implementation agent for the fisheries co-management board, indicate that limited participation in the commercial charr fishery has been due to a lack of skilled fishers with the necessary gear. According to both community members and scientists, given the many uncertainties on the status of the stock, fishing activity around Nain Bay only likely leads to severe depletion of local stocks and increases uncertainty on the potential of future fish production from this area (NAFO, 2008).

According to focus group participants, winter subsistence harvests now suggest that there may be

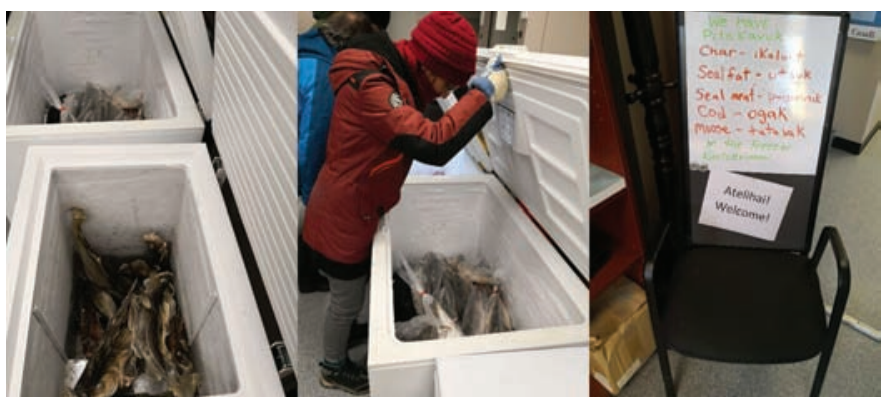

FIG. 2. Community freezer in Nain, November 2018.

healthy charr populations in the bays north of Nain. This proposition remains uncertain, however, as there are no current or recent scientific stock assessments for that area. Due to the lack of funding for stock assessments and the poor understanding of the potential effects of past fish harvests, the fishery management plan for Arctic charr has remained unchanged since the early 1990s. Sporadic attempts to understand specific biological and ecological dimensions of the species and the fishery (e.g., weight declines, trophic ecology, environmental influences on growth, thermal habitat use of juveniles, or more recently genetic studies including effects of climate change) have not been successfully integrated into the management plan (Layton et al., 2020; NAFO, 2019).

The pre- and post-commercial harvesting sector is innately connected to food security in the region. For example, the commercial charr fishery in Nain is supporting food security across Nunatsiavut through a "community freezer program" (Organ, 2014; Fig. 2). Under this program, the Nunatsiavut Government purchases processed char from the Nain processing plant to make it available in the other four coastal communities and in Happy ValleyGoose Bay. The decline in commercial fishery operations has led not only to reductions in employment opportunities and incomes but also to a diminished community freezer supply. Further, the decline of this sector is contributing both to economic inequality and a growing lack of interest by younger generations in the fishery sector.

Similar to the charr fishery, participation in the shrimp, snow crab, and turbot pre- and post-harvesting sectors also is limited, but for a different set of reasons that relate to access to fish stocks, limited regional processing capacities, market conditions, and lack of independent fishing licenses. Despite the adjacency described in the federal government's own policies, the integrated fisheries management plans (IFMPs), and the LILCA, Nunatsiavut has been allowed access through its communal license to only $3.38 \%$ of the Canadian allocation for turbot in both the Northwest Atlantic Fisheries Organization's Subarea 2 and Division 3KLMNO (Fig. 1). Additionally, despite recent increases, allocations to harvest northern shrimp in Shrimp Fishing Areas (SFAs) 4 and 5 remain small at only $10 \%$ and $9.9 \%$, respectively.

The communal licenses through which Nunatsiavut fisheries are managed have been successful in ensuring 


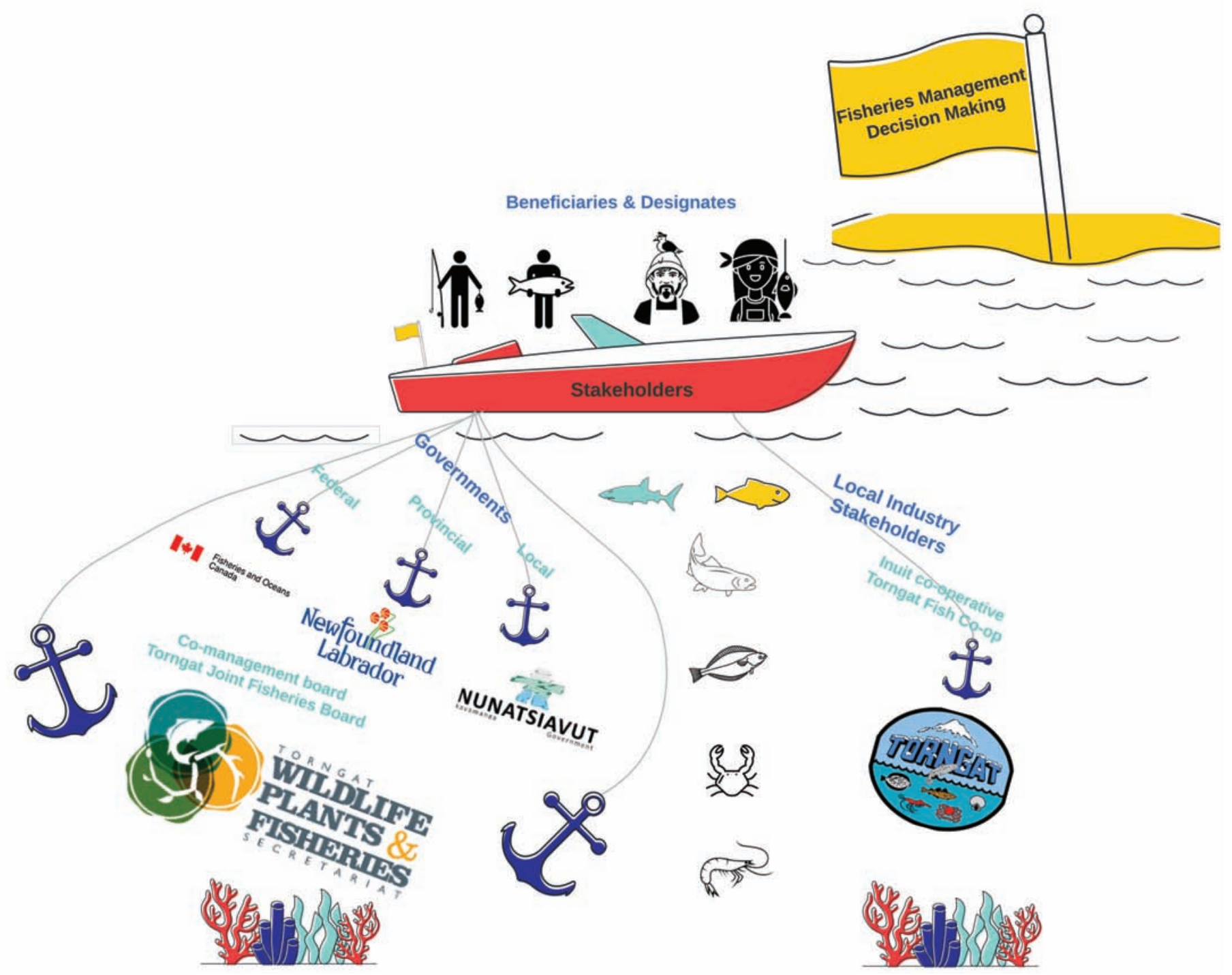

FIG. 3. Schematic of stakeholders involved in decision making and fisheries management of fisheries in Nunatsiavut.

that property rights stay within the communities. However, given the lack of access to capital and permits (e.g., independent licenses that could allow them to invest in boats and fishing equipment), many Nunatsiavut designates enter into lease arrangements with commercial harvesters outside the region who fish their allocations for them. Further, none of the shrimp harvested in Nunatsiavut waters is processed locally, and this situation diminishes the scale of socioeconomic benefits that could otherwise be retained locally. Similar to shrimp, participation in the snow crab fishery has been limited to very few independently owned boats. The lack of local boat ownership and fishing capacity can be attributed in part to the structure of the communal license system in Nunatsiavut.

In addition to these problems of access and allocations, the interests of governments (federal, provincial, local) and management agencies (e.g., co-management boards) that engage in marine resource management differ from one another and do not always align with those of the communities, which may have fundamentally different views on the goals marine resource management should strive to achieve. Fisheries management and decision making in northern Labrador is fragmented, creating barriers to realizing and capturing social and economic benefits of commercial fisheries. Formal communication channels are largely missing among DFO, the Province of Newfoundland and Labrador, the Nunatsiavut Government, the TJFB, the fishing and processing industry (e.g., Torngat Fish Producers Co-Operative), and Nunatsiavut designates and beneficiaries (see schematic in Figure 3, which shows the stakeholders involved in fisheries management and decision making). This lack of a consistent collective approach comes at the cost of improvements in food security that marine resource governance could be contributing to the region. Efforts to ameliorate the lack of communication have been underway for some time, for example, through annual meetings of harvesters organized by the TJFB with participation from DFO, the Nunatsiavut Government, the provincial government, and other stakeholders in the fishery (e.g., Torngat Fish Producers Co-Operative and 
Nunatsiavut Group of Companies). However, these two-day long meetings once per year may be inadequate to integrate views and co-design fisheries management; in many ways, they primarily serve as a forum to share information about the most recent fishing season. Addressing the multiple challenges facing Nunatsiavut fisheries requires a structured and transparent decision-making framework that encourages users and managers to respect the spirit and intent of the LILCA, hold the multiple parties accountable for their responsibilities, and support policymaking that links fisheries management to food production and food security.

\section{KNOWLEDGE GAPS AND BARRIERS TO MONITORING (SEA)FOOD INSECURITY}

The province of Newfoundland and Labrador has, in recent years, been portrayed as a success story in the mitigation of food insecurity (PROOF, 2018), however we argue here that this is likely not the case for northern Labrador. An Inuit health survey conducted in 2007-08 found that household levels of food insecurity occurred at rates of more than $44 \%$ across communities in Nunatsiavut (15.6\% reporting severe food insecurity and $28.6 \%$ moderate food insecurity) (Egeland, 2010). According to the Statistics Canada 2017 Aboriginal Peoples Survey as described in the Inuit Nunangat Food Security Strategy (ITK, 2021), more than $68 \%$ of households experienced food insecurity (note however that the methods and data used differ across sources and time). The documented increase in food insecurity was 7\% between the 2007-08 Inuit health survey and the 2013-14 health survey in Nunatsiavut (McTavish et al., 2017). During 2013-14, more than 60\% of households were found food insecure to some extent, and two of the communities were found to have experienced rates of food insecurity on the order of $80 \%$ (i.e., $79.4 \%$ in Nain and $83.1 \%$ in Hopedale) (Nunatsiavut Government, 2017a). Food insecurity was measured through questions regarding the ability of households to afford food and their experiences with food over a one-month period (PROOF, 2018). Then households were classified as food secure, marginally food insecure, moderately food insecure, or severely food insecure based on the number of affirmative responses (McTavish et al., 2017), but with more specific thresholds for these classifications missing (PROOF, 2018). Despite space for methodological improvements, these efforts draw attention to the problem and open up space for future work in better understanding its magnitude and the failure in addressing it through resource management policies. Embedded in these efforts is also the need to determine targets that define success in mitigating food insecurity.

At the regional level, the Nunatsiavut Government is now working on developing a food security strategy with the support of the federal government (CIRNAC, 2018; OKâlaKatigêt Society, 2018a). A critical element to making this effort a success is close collaboration, consultations, and active engagement with community members in order to better understand the drivers of food insecurity that relate to the management of local natural resources.

As Nunatsiavut communities continue to struggle with food insecurity, more attention needs to shift towards understanding the relative importance of the subsistence and commercial economies. Documenting food insecurity rates helps raise attention, but coordinated efforts that involve locals directly in determining priorities and formulating research questions can help speed the process of producing community-driven tools relevant to the management of traditionally harvested resources.

Results from interviews and focus group discussions in Nain and Makkovik (2019), which were directed towards capturing community priorities for the development of marine resource governance indicators, show that community members feel significantly less empowered to access resources and less able to afford food after the LILCA in 2005, which initiated the self-governance of the region and led to the creation of the Nunatsiavut Government (see also Goldhar et al., 2012:80). These results provide evidence that the views of community members do not always align with the views, goals, and objectives of local and federal authorities involved in decision making for resource governance and planning of resource use.

Despite offering a seat at the table to Inuit organizations, past federal initiatives focused on mitigating food insecurity have not fully recognized the inputs of Inuit. As a consequence, all five major Inuit organizations, including the Nunatsiavut Government, have resigned from the federal government's Indigenous Working Group on food security (Murray, 2018).

Measures to alleviate food insecurity in Nunatsiavut, similar to elsewhere in Inuit Nunangat, have achieved varying degrees of success. Examples include food subsidy programs, such as the federal-run Nutrition North Canada, the efficiency or success of which remains unclear and questionable (OAG, 2014). Other communitylevel initiatives, such as the community freezers, are seen through a more positive lens, given that they align with local Inuit values of sharing and provide access to wild country food traditionally consumed by Inuit (e.g., with respect to Inuit values, see qanuqtuurniq in Aningmiuq and Sarazin (2018:7), which in Inuktut, refers to "innovation" or "resourcefulness," to work together, draw on local knowledge, and overcome the hardships of living in this Arctic region).

The initiative for the community freezers invokes historical seminomadic times when Inuit harvesters would bring food home and store it in the permafrost underground, allowing anyone in the community ready access to calories and nutrients (Aningmiuq and Sarazin, 2018). Today, harvesters can donate excess harvests to the freezer for those community members who cannot undertake harvests themselves (e.g., elders of the community or others in need of nutritious food). 
The freezers are supported in different ways by the communities. In some cases, support occurs through direct food purchases meant to supplement harvested food (Goldhar et al., 2012). In other cases, hunters who supply the freezers are reimbursed for their hunting costs (Aningmiuq and Sarazin, 2018).

Like the community freezer program, other programs have expanded in recent years to accommodate more people in need. For example, in the community of Hopedale, there was an increase of close to $90 \%$ in the number of people using the freezer (Food First NL, 2018). Examples of other programs include food banks, such as the TaKuaKautik Food Bank, a recent community-led, volunteer-based initiative in Nain (OKâlaKatigêt Society, 2018b), and the local Nain Community Food Centre Project aimed at meal planning, preparation, and dissemination, following the guidelines of the Food Guide (for more community programs addressing food insecurity problems in Nunatsiavut, such as the Gardening Program, Community Kitchens Program, Youth Outreach Program, Going Off, Growing Strong Program, and Good Food Box Program, see ITK, n.d.). Despite their success in supporting access to nutritious food, these measures focus more on treating the symptoms of food insecurity instead of directly addressing its causes. Additionally, in spite of the general appeal of programs such as the community freezers, evidence from Nain shows that they may fall short in being inclusive enough and effective in supporting food security in the long run (Organ et al., 2014).

These are only a few selected examples that highlight the need for more robust evidence to understand the contribution of fish and marine mammals to improving food security and nutrition. Laying out the arguments for why it is essential to invest in building a solid understanding of this contribution could spark efforts to better track the subsistence economy and the roles it could play in enhancing food security.

International collaborations and consensus frameworks such as those facilitated by IDA STPI and SAON (2017) and informed by communities themselves can help identify key components of food security and direct efforts and investments for monitoring (Lee et al., 2019). For example, the International Arctic Observations Assessment Framework (IDA STPI and SAON, 2017) has identified accessibility, availability, and sustainability of food, together with safety and exchange practices as key food security focus areas and has specified objectives comprising those focus areas and the means to achieve related goals. Earlier efforts to monitor food security at the circumpolar level (Nilsson et al., 2013) have identified important and feasible-to-measure indicators that broadly capture, both directly and indirectly, natural resource-related trends and the connections of food consumption (including country food) to health, monetary, and non-monetary accessibility to food.

The implementation of many of these indicators is still nascent and exploratory, signifying needs and priorities at a high level, with further action pending upon national efforts and investments. Challenges also remain in translating broader food security frameworks (e.g., see also ICC-AK, 2015) into needs for observations, monitoring, and concrete strategies. We argue here that narrowing down the indicators that capture the food security dimensions related to marine resources, while considering regional needs and practices, is key for incorporating these monitoring needs in management plans and stimulating local action involving the communities themselves. Such efforts, focused on the marine and coastal environment, are more prominent in the Pacific Arctic, with ongoing efforts to develop a roadmap for observing needs and actions, applicable at the panArctic scale (NSF, 2020).

Through highlighting the key resource management policy gaps, we hope to spur interest in and attention to the development of robust, meaningful, and measurable indicators to help Nunatsiavut communities track, in a consistent manner throughout time, the contribution of marine resources to diet and to understand their contributions to food security. Some examples of an initial set of such straightforward, easy to capture indicators include:

- Compilations of annual harvest and consumption of subsistence marine biomass (fish or mammals) per household;

- Compilations of annual harvest and consumption of commercial marine biomass per household;

- Compilations of per capita annual consumption of combined subsistence and commercial marine biomass as a percentage of per capita total protein intake;

- Estimated contributions of the consumption of combined subsistence and commercial marine biomass to reductions in adverse health outcomes related to nutritional deficiencies or imbalances (e.g., obesity, diabetes, hypertension, heart disease, cancer, and others);

- Estimated reductions in food insecurity due to social norms or formal government programs comprising food sharing or other forms of nutritional support (e.g., the use of community freezers).

These broad categories of indicators are the result of the authors' research in the region, which includes the aforementioned focus groups with community members and interviews and consultations with local stakeholders, combined with relevant literature and frameworks such as those in Moller et al. (2004), Jollands and Harmsworth (2007), Fedirchuk et al. (2008), Ford (2009), Wesche and Chan (2010), CBD (2013), Nilsson et al. (2013), IRC (2019), and Lysenko and Schott (2019).

A first step could be for fisheries regulators to prioritize research needs in line with the implications for food security as informed by the indicators. Identifying research needs should be a community-driven process with research efforts directly involving locals in the research process to 
produce informative indicators that suit the needs of and empower marine resource users rather than following a Western paradigm of setting research priorities.

Historically, in other parts of the Arctic, scientists have focused on monitoring the health of natural resource stocks important to subsistence harvesting, such as beluga whales (Loseto et al., 2008, 2018; Choy et al., 2017; MacMillan et al., 2019). Integrating community perspectives has led to a more holistic approach focused on individual beluga health and how this can translate into increased food safety and security (Ostertag et al., 2018). For Inuit in the Inuvialuit Settlement Region, these research endeavors are important because they address long-standing concerns about beluga health, whether and how subsistence takes can be continued, and adaptation to ongoing environmental changes. The beluga monitoring program has grown over the past 10 years to include increased sampling and to incorporate health concerns of users and beluga-specific indicators to meet the needs of the communities (Loseto et al., 2018; MacMillan et al., 2019). Its success lies in the inclusionary approach to knowledge co-production, where bridging Western science and Indigenous knowledge has led to the co-development of new research questions, programs and potential indicators to serve as co-produced indicators. These indicators successfully cross the boundaries between scientific knowledge holders, managers, and Inuit hunters and are better suited to serve Inuit needs and perspectives (Kourantidou et al., 2020).

The co-development of indicators is essential for effectively addressing marine resource management issues and food insecurity concerns from the lens of those who experience them. Efforts to monitor indicators like the ones described above can help to improve not only marine resource management but also foster (sea) food sovereignty among Inuit communities, including greater self-determination and cultural revitalization of traditional values that relate to harvesting and sharing country food. Long-term monitoring efforts also can help Inuit communities build resilience in the face of changing environmental conditions and marine resource governance systems. Local observations, narratives, and TEK are all critical to informing the selection of these indicators; however, recognizing these insights along with Western science and practices remains a challenge (Kourantidou et al., 2020). In recent years much effort has been leveled at community-based monitoring and other participatory initiatives that build upon TEK across Inuit Nunangat (Johnson et al., 2015), including in Nunatsiavut (Nunatsiavut Government, 2017b), which contribute directly and indirectly to marine resource monitoring and observing needs relevant to monitoring food security. Progress however is in some cases limited by observational challenges related to the high costs of data collection and monitoring of fish and marine mammal stocks and subsistence harvests in geographically remote locations.

\section{CHARTING THE PATH FORWARD}

With marine resource management across Inuit Nunangat increasingly informed by broader-scope federal policy frameworks for the Arctic, it becomes timely and relevant to flesh out the discourse on food security.

In September 2019 the Government of Canada launched the "Arctic and Northern Policy Framework," which sets out its long-term vision to guide investments and actions in the region to 2030 (CIRNAC, 2019). Co-development, collaborative governance, and Inuit inclusion are at the forefront of the new policy, in recognition of past shortsighted and ineffective policy responses which were the outcome of lack of consultation with Inuit (Kikkert and Lackenbauer, 2019). Despite the criticism it has received as a partially developed document lacking concrete strategies and with the timing of its release driven by the 2019 federal elections, it is seen as a commitment and preliminary guide for implementation that can help secure the necessary funds for more concrete initiatives to follow. With secured funding for community-led food production projects, skills training for local and Indigenous food production systems, and a dedicated Inuit Nunangat chapter, the new policy purports to "strengthen food security" and to "reinforce Indigenous connections with wildlife and the land" (CIRNAC, 2019).

The examples of past action referenced in the new policy in support of this goal include, 1) investments in the heavily criticized Nutrition North program, 2) the food security group from which Inuit organizations previously resigned in absence of meaningful dialogue, and 3) the Harvesters Support Grant, a program recently added to Nutrition North (NNC, 2021), intended to lower the costs of traditional harvesting, but with no further details in the policy on ways of implementation. Notably, there is no clear stance on biodiversity conservation; the new policy recognizes the diversity of concerns over reducing development impacts on wildlife that are part of Inuit peoples' subsistence diet as well as calls for reducing the weight of regulation. The new policy also acknowledges that eliminating food insecurity is related to both the affordability of store-bought foods and access to traditional food and brings forward climate change-related risks and uncertainties as key drivers of rising food insecurity in the region.

In the international chapter of the new policy (CIRNAC, 2019), there are commitments for collaboration with other Arctic states to "increase the region's food production in support of enhanced food security," possibly in recognition of multiple migratory species, the decline of which disproportionately affects Inuit due to inadequate management in areas beyond national jurisdiction (Vierros et al., 2020). Those commitments though lack details and are limited to increasing large-scale efforts on scientific research and monitoring (e.g., tied to the agreement on unregulated fishing in the Central Arctic Ocean).

In October 2018, DFO, the Canadian Coast Guard, and the Inuit Tapiriit Kanatami (a national Inuit advocacy 
non-governmental organization) announced the creation of a new stand-alone "Arctic Region" that includes all four regions of Inuit Nunangat and adds to DFO's six administrative regions and the Coast Guard's three operational regions (DFO, 2018). Embedded in the design of the new Arctic region, the borders and activities within it, are active engagement and inclusion of Inuit in the decision-making process (DFO, 2019). Although the announcement lacked details or other concrete strategies, and despite the fact that co-management boards were not engaged prior to the announcement, it was generally seen through a positive lens. Specifically, the commitment to advancing reconciliation through the new Arctic region was perceived by co-management boards in the Eastern Arctic (Nunavut Wildlife Management Board, Nunavik Marine Region Wildlife Board, and TJFB) as a potential opportunity for collaboration with the federal government in designing fisheries management and jointly identifying research priorities (Snook et al., 2019b). The general lack of collaboration in the past has posed barriers to identifying key resource management challenges driving high food insecurity rates.

\section{CONCLUSIONS}

This paper has briefly discussed the need for integration among marine resource management, health, and economic development policies in ways that could contribute to Inuit food security. As a relevant case, we have considered the self-governing region of Nunatsiavut, where commercial fisheries and other subsistence marine resources are essential to the livelihoods and nutritional status of individuals and communities. Our analysis has been informed by the observations, views, and perceptions of community members engaged in harvesting or processing now and in the past.

The foregone economic opportunities from lack of access to commercial fishing grounds and fish stocks adjacent to Nunatsiavut, along with barriers to growth in the post-harvesting sector, trigger risks for increasing food insecurity in the region. Socioeconomic benefits from commercial fisheries are leaking out of Nunatsiavut due to allocations that do not align with commitments of the federal government and federal mandates for the region's fisheries management. The loss of access to both commercial and subsistence fisheries has led to widespread food insecurity that threatens the health of individual Inuit and the well-being of their communities in the long run.

Understanding the subsistence economy, which has been largely understudied to date, is key to managing marine resources so that access to food is established and safeguarded. The current limited capacity of Inuit peoples to participate in the subsistence economy heightens food insecurity risks for reasons that include the degradation of TEK and its transfer across generations. We propose that monitoring is key to building a deeper understanding of the critical importance of the subsistence economy, and we suggest the development of robust, meaningful, and measurable indicators that allows for tracking the contributions of marine resources to diet and food security.

Integrating missing local perspectives on marine resource governance also is central to addressing the persistent problem of food insecurity among Inuit peoples. Despite recognizing the high levels of food insecurity among Inuit, the institutional mechanisms to address them fail to fully incorporate issues of marine resource governance, focusing on the symptoms of food insecurity, not the causes. Increased access to subsistence and commercial fisheries is fundamental to food security in northern Labrador. In order to successfully address the problem in the long run, these linkages need to be reflected substantively in Canadian federal food policy that currently relies primarily on short-term response strategies.

\section{ACKNOWLEDEMENTS}

This research was undertaken with funding from the Canada First Research Excellence Fund through the Ocean Frontier Institute (MK and $\mathrm{MB}$ ) and the Johnson Endowment of the Woods Hole Oceanographic Institution's (WHOI) Marine Policy Center (PH). The authors thank Jamie Snook and Aaron Dale from the Torngat Secretariat and Todd Broomfield from the Nunatsiavut Government for conversations that influenced this work.

\section{REFERENCES}

Agriculture and Agri-Food Canada. 2019. Food policy for Canada: Everyone at the table.

https://www.canada.ca/en/campaign/food-policy/ thefoodpolicy.html

Allard, M., and Lemay, M., eds. 2012. Nunavik and Nunatsiavut: From science to policy. An integrated regional impact study (IRIS) of climate change and modernization. Québec City: ArcticNet Inc.

Aningmiuq, A., and Sarazin, T. 2018. A path to community driven food innovation. Stanford Social Innovation Review 16(1): A7. https://ssir.org/articles/entry/a_path_to_community_driven food_innovation

Beaumier, M.C., and Ford, J.D. 2010. Food insecurity among Inuit women exacerbated by socio-economic stresses and climate change. Canadian Journal of Public Health 101(3):196-201. https://doi.org/10.1007/BF03404373

Borish, D., Cunsolo, A., Snook, J., Shiwak, I., Wood, M., HERD Caribou Project Steering Committee, Mauro, I., Dewey, C., and Harper, S.L. 2021. "Caribou was the reason, and everything else happened after": Effects of caribou declines on Inuit in Labrador, Canada. Global Environmental Change 68: 102268. https://doi.org/10.1016/j.gloenvcha.2021.102268 
Breton-Honeyman, K., Hammill, M.O., Furgal, C.M., and Hickie, B. 2016. Inuit knowledge of beluga whale (Delphinapterus leucas) foraging ecology in Nunavik (Arctic Quebec), Canada. Canadian Journal of Zoology 94(10):713-726.

https://doi.org/10.1139/cjz-2015-0259

Brook, R.K., Kutz, S.J., Veitch, A.M., Popko, R.A., Elkin, B.T., and Guthrie, G. 2009. Fostering community-based wildlife health monitoring and research in the Canadian North. EcoHealth 6(2):266-278. https://oi.org/10.1007/s10393-009-0256-7

Burnett, K., Hay, T., and Chambers, L. 2016. Settler colonialism, Indigenous peoples and food: Federal Indian policies and nutrition programs in the Canadian North since 1945. Journal of Colonialism and Colonial History 17(2).

https://doi.org/10.1353/cch.2016.0030

Casimirri, G. 2003. Problems with integrating traditional ecological knowledge into contemporary resource management. XII World Forestry Congress, 21 - 28 September 2003, Québec City. http://www.fao.org/3/XII/0887-A3.htm

CBC. 1973. Land \& sea: The people of the Torngats. Video. https://www.cbc.ca/news/canada/new foundland-labrador/ inuit-nain-okak-arctic-char-torngats-labrador-1.4216082

CBD (Convention of Biological Diversity). 2013. Indicators relevant for traditional knowledge and customary sustainable use. UNEP/CBD/WG8J/8/9. Nairobi, Kenya: UNEP.

https://www.cbd.int/doc/meetings/tk/8jws-2014-03/ information/8jws-2014-03-wg8j-08-09-en.pdf

Chapman, J.M., and Schott, S. 2020. Knowledge coevolution: Generating new understanding through bridging and strengthening distinct knowledge systems and empowering local knowledge holders. Sustainability Science 15:931-943. https://doi.org/10.1007/s11625-020-00781-2

Choy, E.S., Rosenberg, B., Roth, J.D., and Loseto, L.L. 2017. Inter-annual variation in environmental factors affect the prey and body condition of beluga whales in the eastern Beaufort Sea. Marine Ecology Progress Series 579:213-225. https://doi.org/10.3354/meps12256

CIRNAC (Crown-Indigenous Relations and Northern Affairs Canada). 2005. Labrador Inuit Land Claims Agreement Act. S.C. 2005, c. 27. Ottawa: Government of Canada.

https://laws-lois.justice.gc.ca/eng/annualstatutes/2005_27/ FullText.html?wbdisable $=$ true

- 2018. New federal funding to strengthen Nunatsiavut's capacity to address climate change impacts. Ottawa: Government of Canada.

ht t p s://w w w. can a d a c a/en/indigenous northern-affairs/news/2018/02/new_federal_ fundingtostrengthennunatsiavutscapacitytoaddressclim.html 2019. Canada's Arctic and Northern policy framework. Ottawa: Government of Canada.

h t t p s : / / w w w. r c a a n c - c i r n a c.g c . c a / eng/1560523306861/1560523330587

Coady, L.W., and Best, C.W. 1976. Biological and management investigations of the Arctic char fishery at Nain, Labrador. Fisheries and Marine Service Technical Report No. 624. 42nd technical report from the Research and Development Directorate Newfoundland Biological Station: St. Johns, NL.
Cooke, S.J., Nguyen, V M., Chapman, J.M., Reid, A.J., Landsman, S.J., Young, N., Hinch, S.G., Schott, S., Mandrak, N.E., and Semeniuk, C.A.D. 2021. Knowledge co-production: A pathway to effective fisheries management, conservation, and governance. Fisheries 46(2):89-97.

https://doi.org/10.1002/fsh.10512

COSEWIC (Committee on the Status of Endangered Wildlife in Canada). 2017. COSEWIC assessment and status report on the caribou, Rangifer tarandus, eastern migratory population, Torngat Mountains population in Canada. Ottawa: COSEWIC. https://publications.gc.ca/collections/collection_2018/eccc/ CW69-14-754-2017-eng.pdf

Couturier, S., Dale, A., Mitchell Foley, J., Snook, J., and Wood, B. 2015. First scientific data on herd size and population dynamics of the Torngat Mountains caribou herd. Happy Valley-Goose Bay, Newfoundland and Labrador: Torngat Wildlife, Plants and Fisheries. Secretariat. 54 p.

Dempson, B. 2008. Ecology and population dynamics of North Labrador Arctic charr: A model species for evaluating impacts of exploitation and climate influences on population characteristics. In: Bell, T., Jacobs, J.D., Munier, A., Leblanc, P., and Trant, A., eds. Climate change and renewable resources in Labrador: Looking toward 2050. Proceedings and report of a conference held in North West River, Labrador, 11-3 March. St. John's: Labrador Highlands Research Group, Memorial University of Newfoundland. 62-67.

DFO (Department of Fisheries and Oceans Canada). 2018. Fisheries and Oceans Canada, the Canadian Coast Guard and Inuit Tapiriit Kanatami announce new Arctic Region. Ottawa: Government of Canada.

https://www.canada.ca/en/fisheries-oceans/news/2018/10/ fisheries-and-oceans-canada-the-canadian-coast-guard-andinuit-tapiriit-kanatami-announce-new-arctic-region.html

. 2019. Engagement on Fisheries and Oceans Canada and the Canadian Coast Guard's new Arctic regions. Ottawa: Government of Canada.

https://www.dfo-mpo.gc.ca/fisheries-peches/consultation/ consult-arct-eng.html

2020. Atlantic salmon - Newfoundland and Labrador region. Ottawa: Government of Canada.

https://www.dfo-mpo.gc.ca/fisheries-peches/ifmp-gmp/ salmon-saumon/2020/index-eng.html

Donaldson, S.G., Curren, M.S., Adlard, B., Provost, J., Leech, T., Tikhonov, C., Feeley, M., Tomlinson, S., and Shearer, R. 2013. Future human health research directions for the Canadian Northern Contaminants Program. International Journal of Circumpolar Health, 72(1): 23049. https://doi.org/10.3402/ijch.v72i0.23049

Durkalec, A., Furgal, C., Skinner, M.W., and Sheldon, T. 2015. Climate change influences on environment as a determinant of Indigenous health: Relationships to place, sea ice, and health in an Inuit community. Social Science \& Medicine 136137:17-26.

https://doi.org/10.1016/j.socscimed.2015.04.026 
Egeland, G.M. 2010. Inuit Health Survey 2007-2008: Nunatsiavut. Ste-Anne-de-Bellevue, Québec: Centre for Indigenous Peoples' Nutrition and Environment.

https://www.mcgill.ca/cine/files/cine/adult_report_nunatsiavut.pdf

FAO (Food and Agriculture Organization of the United Nations). 1996. Rome declaration on world food security and world food summit plan of action. World Food Summit, 13-17 November 1996, Rome, Italy. Rome: FAO.

https://www.fao.org/3/w3613e/w3613e00.htm

_ _ 2001. The state of food insecurity in the world. Rome: FAO.

https://www.fao.org/3/y1500e/y1500e01.htm\#P0_0

Fedirchuk, G.J., Labour, S., and Niholls, N. 2008. Traditional knowledge guide for the Inuvialuit Settlement region, Northwest Territories. Volume II: Using traditional knowledge in impact sssessments. Environmental Studies Research Funds Report No. 153. Calgary. 104 p.

https://publications.gc.ca/collections/collection_2008/nebone/NE22-4-153E-2.pdf

Fergurson, H. 2011. Inuit food (in)security in Canada: Assessing the implications and effectiveness of policy. Queen's Policy Review 2(2):54-79.

Food First NL. 2018. Expansion of the Community Freezer Program in Hopedale.

https://www.foodfirstnl.ca/expansion-of-the-communityfreezer-program-in-hopedale

Ford, J.D. 2009. Vulnerability of Inuit food systems to food insecurity as a consequence of climate change: A case study from Igloolik, Nunavut. Regional Environmental Change 9(2):83-100.

https://doi.org/10.1007/s10113-008-0060-x

Goldhar, C., Bell, T., Sheldon, T., Andersen, T., Piercy, W., Gear, D., Wolfrey, C., et al. 2012. SakKijânginnatuk Nunalik: Understanding opportunities and challenges for sustainable communities in Nunatsiavut, learning from the coast. Nain: Nunatsiavut Government.

Government of Newfoundland and Labrador. 2013. Hunting ban announced on George River caribou herd.

https://www.releases.gov.nl.ca/releases/2013/env/0128n08.htm

Group ATN. 2018. Nunatsiavut fisheries socio-economic analysis. Halifax, Nova Scotia: Group ATN Consulting Inc. 202-1883 Upper Water St. Halifax, Nova Scotia B3J 1S9, Canada. 19 p.

Health Canada. 2019. Canada's dietary guidelines for health professionals and policy makers. Ottawa: Health Canada. https://publications.gc.ca/collections/collection_2019/sc-hc/ H164-231-2019-eng.pdf

Hoover, C., Bailey, M., Higdon, J., Ferguson, S.H., and Sumaila, R. 2013. Estimating the economic value of narwhal and beluga hunts in Hudson Bay, Nunavut. Arctic 66(1):1-16. https://doi.org/10.14430/arctic4261

Hoover, C., Snook, J., Akearok, J., Pallister, T., Giles, A., Basterfield, M., Dale, A., Kourantidou, M., Cunsolo, A., and Bailey, M. In press. Chapter 10: The role of fisheries comanagement in addressing access and allocation inequalities in Eastern Inuit Nunangat. In: Sumaila, U.R., Armitage, D., Bailey, M., and W. Cheung, W., eds. Canada's oceans: Pathways to sustainability in a sea of change. Vancouver: UBC Press.
Hoover, E. 2017. "You can't say you're sovereign if you can't feed yourself": Defining and enacting food sovereignty in American Indian community gardening. American Indian Culture and Research Journal 41(3):31-70.

https://doi.org/10.17953/aicrj.41.3.hoover

Huet, C., Rosol, R., and Egeland, G.M. 2012. The prevalence of food insecurity is high and the diet quality poor in Inuit communities. The Journal of Nutrition 142(3):541 - 547. https://doi.org/10.3945/jn.111.149278

Huntington, H.P., Brown-Schwalenberg, P.K., Frost, K.J., Fernandez-Gimenez, M.E., Norton, D.W., and Rosenberg, D.H. 2002. Observations on the workshop as a means of improving communication between holders of traditional and scientific knowledge. Environmental Management 30(6):778 - 792. https://oi.org/10.1007/s00267-002-2749-9

Huntington, H.P., Quakenbush, L.T., and Nelson, M. 2016. Effects of changing sea ice on marine mammals and subsistence hunters in northern Alaska from traditional knowledge interviews. Biology Letters 12(8): 20160198. https://doi.org/10.1098/rsbl.2016.0198

- 2017. Evaluating the effects of climate change on indigenous marine mammal hunting in Northern and Western Alaska using traditional knowledge. Frontiers in Marine Science 4: 319. https://doi.org/10.3389/fmars.2017.00319

ICC-AK (Inuit Circumpolar Council-Alaska). 2015. Alaskan Inuit food security conceptual framework: How to assess the Arctic from an Inuit perspective. Technical Report. Anchorage: ICCAK.

https://circumpolar.org/wp-content/uploads/2016/10/Reportsby-Indigenous-Peoples-1.pdf

IDA STPI and SAON (IDA Science and Technology Policy Institute and Sustaining Arctic Observing Networks). 2017. International Arctic observations assessment framework. Washington, D.C.: IDA STPI, and Oslo: SAON. 73 p. https://www.arcticobserving.org/images/pdf/misc/STPISAON-International-Arctic-Observations-FrameworkReport-2017.pdf

IRC (Inuvialuit Regional Corporation). 2019. Indicators. Inuvik: IRC.

https://indicators.inuvialuit.com/Indicators

ITK (Inuit Tapiriit Kanatami) n.d. NiKigijavut Nunatsiavutinni (Our food in Nunatsiavut) Project. 2013-2017.

https://www.itk.ca/nuluaq-mapping-project/initiative/ nikigijavut-nunatsiavutinni-our-food-in-nunatsiavut-project/

. 2017. An Inuit-specific approach for the Canadian Food Policy. Ottawa: ITK.

https:/www.itk.ca/wp-content/uploads/2019/01/ITK_FoodPolicy-Report.pdf

_. 2021. Inuit Nunangat food security strategy. Ottawa: ITK. https:/www.itk.ca/inuit-nunangat-food-security-strategy/

Johnson, N., Alessa, L., Behe, C., Danielsen, F., Gearheard, S., Gofman-Wallingford, V., Kliskey, A., et al. 2015. The contributions of community-based monitoring and traditional knowledge to Arctic observing networks: Reflections on the state of the field. Arctic 68(Suppl. 1): 28-40.

https://doi.org/10.14430/arctic4447 
Jollands, N., and Harmsworth, G. 2007. Participation of Indigenous groups in sustainable development monitoring: Rationale and examples from New Zealand. Ecological Economics 62(34):716-726. https://doi.org/10.1016/j.ecolecon.2006.09.010

Kaiser, B.A., Hoeberechts, M., Maxwell, K.H., Eerkes-Medrano, L., Hilmi, N., Safa, A., Horbel, C., et al. 2019. The importance of connected ocean monitoring knowledge systems and communities. Frontiers in Marine Science 6: 309. https://doi.org/10.3389/fmars.2019.00309

Kenny, T. 2017. The Inuit food system: Ecological, economic, and environmental dimensions of the nutrition transition. $\mathrm{PhD}$ thesis, University of Ottawa.

Kikkert, P., and Lackenbauer, P.W. 2019. Canada's Arctic and Northern Policy Framework: A roadmap for the future? Arctic Yearbook 2019: Briefing Notes. Akureyri, Iceland: Arctic Portal.

https://arcticyearbook.com/arctic-yearbook/2019/2019briefing-notes/332-canada-s-arctic-and-northern-policyframework-a-roadmap-for-the-future

Knopp, J.A., Furgal, C.M., Reist, J.D., Babaluk, J.A., Sachs Harbour Hunters and Trappers Committee, and Olokhaktomiut Hunters and Trappers Committee. 2012. Indigenous and ecological knowledge for understanding Arctic char growth. In: Carothers, C., Criddle, K.R., Chambers, C.P., Cullenberg, P.J., Fall, J.A., Himes-Cornell, A.H., Petter Johnsen, J., Kimball, N.S., Menzies, C.R., and Springer, E.S., eds. Fishing people of the North: Cultures, economies, and management responding to change. Fairbanks: Alaska Sea Grant. 177-192. https://doi.org/10.4027/fpncemrc.2012.14

Kourantidou, M., Hoover, C., and Bailey, M. 2020. Conceptualizing indicators as boundary objects in integrating Inuit knowledge and Western science for marine resource management. Arctic Science 6(3):279-306. https://doi.org/10.1139/as-2019-0013

Kourantidou, M., Hoagland, P., Dale, A., and Bailey, M. 2021. Equitable allocations in northern fisheries: Bridging the divide for Labrador Inuit. Frontiers in Marine Science 8:590213. https://doi.org/10.3389/fmars.2021.590213

Kourantidou, M., Jin, D., and Solow, A. 2022. Bioeconomic analysis accounting for environmental effects in data-poor fisheries: The northern Labrador Arctic char. Canadian Journal of Fisheries and Aquatic Sciences 79(1):82-96. https://doi.org/10.1139/cjfas-2021-0077

Laird, B.D., Goncharov, A.B., Egeland, G.M., and Chan, H.M. 2013. Dietary advice on Inuit traditional food use needs to balance benefits and risks of mercury, selenium, and n3 fatty acids. The Journal of Nutrition 143(6):923-930. https://doi.org/10.3945/jn.112.173351

Laugrand, F., and Oosten, J. 2009. Transfer of Inuit qaujimajatuqangit in modern Inuit society. Études/Inuit/ Studies 33(1-2):115-152.

https://doi.org/10.7202/044963ar
Layton, K.K.S., Dempson, B.J., Snelgrove, P.V.R., Duffy, S.J., Messmer, A.M., Paterson, I.G., Jeffery, N.W., et al. 2020. Resolving fine-scale population structure and fishery exploitation using sequenced microsatellites in a northern fish. Evolutionary Applications 13(5):1055-1068.

https://doi.org/10.1111/eva.12922

Lee, C.M., Starkweather, S., Eicken, H., Timmermans, M.-L., Wilkinson, J., Sandven, S., Dukhovskoy, D., et al. 2019. A framework for the development, design and implementation of a sustained Arctic Ocean observing system. Frontiers in Marine Science 6: 451. https://doi.org/10.3389/fmars.2019.00451

Loseto, L.L., Stern, G.A., and Ferguson, S.H. 2008. Size and biomagnification: How habitat selection explains beluga mercury levels. Environmental Science \& Technology 42(11):3982-3988. https://doi.org/10.1021/es7024388

Loseto, L.L., Hoover, C., Ostertag, S., Whalen, D., Pearce, T., Paulic, J., Iacozza, J., and MacPhee, S. 2018. Beluga whales (Delphinapterus leucas), environmental change and marine protected areas in the Western Canadian Arctic. Estuarine, Coastal and Shelf Science 212:128-137.

https://doi.org/10.1016/j.ecss.2018.05.026

Lysenko, D., and Schott, S. 2019. Food security and wildlife management in Nunavut. Ecological Economics 156:360-374. https://doi.org/10.1016/j.ecolecon.2018.10.008

MacMillan, K., Hoover, C., Iacozza, J., Peyton, J., and Loseto, L. 2019. Body condition indicators: Assessing the influence of harvest location and potential thresholds for application in beluga monitoring. Ecological Indicators 104:145-155.

https://doi.org/10.1016/j.ecolind.2019.04.012

McTavish, K., Furgal, C., Martin, R., Willson, E., and IHACC Team. 2017. Inuit food security in Nunatsiavut: The communityspecific nature of a widespread public health issue. ArcticNet Conference poster. Arctic Change 2017, 11-15 December, Québec City.

https://arcticnetmeetings.ca/ac2017/docs/poster-ac2017/ Health_Kristeen_McTavish.pdf

Moller, H., Berkes, F., Lyver, P.O., and Kislalioglu, M. 2004. Combining science and traditional ecological knowledge: Monitoring populations for co-management. Ecology and Society 9(3): 2 . https://doi.org/10.5751/ES-00675-090302

Muir, D.C.G., Shearer, R.G., Van Oostdam, J., Donaldson, S.G., and Furgal, C. 2005. Contaminants in Canadian Arctic biota and implications for human health: Conclusions and knowledge gaps. Science of the Total Environment 351-352:539-546. https://doi.org/10.1016/j.scitotenv.2005.08.030

Murray, N. 2018. "Tokenism and optics": Inuit orgs slam feds on Nutrition North consultations. CBC News, October 19. https://www.cbc.ca/news/canada/north/inuit-groupsindigenous-working-group-nutrition-north-1.4869314

NAFO (Northwest Atlantic Fisheries Organization). 2008. Canadian Research Report for 2008: Newfoundland and Labrador Region. NAFO SCS Doc. 09/13, Serial No. N5644. Scientific Council Meeting - June 2008. Halifax, Nova Scotia: NAFO. https://www.nafo.int/Portals/0/PDFs/sc/2009/scs09-13.pdf 
2019. Canadian Research Report for 2018 Newfoundland and Labrador Region. NAFO SCS Doc. 19/13, Serial No. N6953. Scientific Council Meeting - June 2019. Halifax, Nova Scotia: NAFO.

https://www.nafo.int/Portals/0/PDFs/sc/2019/scs19-13.pdf

Nilsson, L.M., Destouni, G., Berner, J., Dudarev, A.A., Mulvad, G., Odland, J.Ø., Parkinson, A., Tikhonov, C., Rautio, A., and Evengård, B. 2013. A call for urgent monitoring of food and water security based on relevant indicators for the Arctic. Ambio 42(7):816-822. https://doi.org/10.1007/s13280-013-0427-1

NNC (Nutrition North Canada). 2021. Support for traditional hunting and harvesting: How the Harvesters Support Grant works, eligible communities and funding streams.

h t t p s:// w w w. nutritionnorthcanada.g c . ca/ eng/1586274027728/1586274048849

NSF (National Science Foundation). 2020. Research networking activities in support of sustained coordinated observations of Arctic change.

https://www.nsf.gov/awardsearch/showAward?AWD_ $\mathrm{ID}=1936805$

Nunatsiavut Government. 2017a. Household Food Security Survey results released. Media release, 23 May.

http://www.nunatsiavut.com/wp-content/uploads/2017/05/ NEWS-RELEASE-Food-security-survey-results-released.pdf

. 2017b. Immapivut ("our oceans"): Nunatsiavut Marine Plan.

https://imappivut.com/about/

Nunavut Food Security Coalition. 2014. Nunavut food security strategy and action plan 2014-16.

https://www.nunavutfoodsecurity.ca/sites/default/files/ files/Resources/Strategy/NunavutFoodSecurityStrategy_ ENGLISH.pdf

OAG (Office of the Auditor General of Canada). 2014. Chapter 6-Nutrition North Canada-Aboriginal Affairs and Northern Development Canada. 2014 Fall Report of the Auditor General of Canada. Ottawa: OAG.

https://www.oag-bvg.gc.ca/internet/English/parl_ oag_201411_06_e_39964.html\#hd3c

OKâlaKatigêt Society. 2018a. Nunatsiavut Government working on food security strategy Radio interview with Kristeen McTavish, the Food Security Coordinator for the Nunatsiavut Government.

http://www.oksociety.com/nunatsiavut-government-workingon-food-security-strategy-audio/

. 2018b. TaKuaKautik food bank. Nain, Nunatsiavut.

http://www.oksociety.com/takuakautik-food-bank/

Organ, J., Castleden, H., Furgal, C., Sheldon, T., and Hart, C. 2014. Contemporary programs in support of traditional ways: Inuit perspectives on community freezers as a mechanism to alleviate pressures of wild food access in Nain, Nunatsiavut. Health \& Place 30:251-259.

https://doi.org/10.1016/j.healthplace.2014.09.012
Orttung, R. 2019. Working for food security in Interior Alaska. Witness Community Highlights, 31 July 2019. Fairbanks: Arctic Research Consortium of the United States. https://www.arcus.org/witness-the-arctic/2019/7/highlight/1

Ostertag, S.K., Loseto, L.L., Snow, K., Lam, J., Hynes, K., and Gillman, D.V. 2018. "That's how we know they"re healthy": The inclusion of traditional ecological knowledge in beluga health monitoring in the Inuvialuit Settlement Region. Arctic Science 4(3):292-320. https://doi.org/10.1139/as-2017-0050

Pearce, T., Ford, J., Cunsolo Willox, A., and Smit, B. 2015. Inuit traditional ecological knowledge (TEK), subsistence hunting and adaptation to climate change in the Canadian Arctic. Arctic 68(2):233-245.

https://doi.org/10.14430/arctic4475

PROOF. 2018. Household food insecurity in Canada: A guide to measurement and interpretation. Toronto: PROOF.

https://proof.utoronto.ca/resources/measurement-guide/

Schrank, W.E., and Roy, N. 2013. The Newfoundland fishery and economy twenty years after the northern cod moratorium. Marine Resource Economics 28(4):397-413.

https://doi.org/10.5950/0738-1360-28.4.397

Searles, E. 2002. Food and the making of modern Inuit identities. Food and Foodways 10(1-2):55-78.

https://doi.org/10.1080/07409710212485

Snook, J., Akearok, J., Palliser, T., Cunsolo, A., Hoover, C., and Bailey, M. 2019a. Enhancing fisheries co-management in the Eastern Arctic. Northern Public Affairs 6(2):70-74.

https://www.northernpublicaffairs.ca/index/volume6-special-issue-2-special-issue-on-modern-treatyimplementation-research/enhancing-fisheries-comanagement-in-the-eastern-arctic/

- 2019b. "The opportunity for Inuit in the commercial fishery is pretty significant": Enhancing fisheries comanagement in the Eastern Arctic.

https://www.torngatsecretariat.ca/home/files/cat2/2019enhancing_fisheries_co-management_in_the_eastern_arctic. pdf

Vierros, M.K., Harrison, A.-L., Sloat, M.R., Ortuño Crespo, G., Moore, J.W., Dunn, D.C., Ota, Y., et al. 2020. Considering Indigenous Peoples and local communities in governance of the global ocean commons. Marine Policy 119: 104039.

https://doi.org/10.1016/j.marpol.2020.104039

Wenzel, G.W. 1978. The harp-seal controversy and the Inuit economy. Arctic 31(1):2-6. https://doi.org/10.14430/arctic2636

- 1985. Marooned in a blizzard of contradictions: Inuit and the anti-sealing movement. Études/Inuit/Studies 9(1):77-91.

Wesche, S.D., and Chan, H.M. 2010. Adapting to the impacts of climate change on food security among Inuit in the Western Canadian Arctic. EcoHealth 7(3):361-373. https://doi.org/10.1007/s10393-010-0344-8 
Wilson, K.S., Basterfield, M.W., Furgal, C., Sheldon, T., Allen, E., the Communities of Nain and Kangiqsualujjuaq, and the Co-operative Management Board for the Torngat Mountains National Park. 2014. Across borders, for the future: Torngat Mountains caribou herd Inuit knowledge, culture, and values study. Final Report to the Nunatsiavut Government and Makivik Corporation, Parks Canada, and the Torngat Wildlife and Plants Co-Management Board. Nain, Newfoundland and Labrador: Torngat Secretariat. $88 \mathrm{p}$.

https://www.torngatsecretariat.ca/home/files/cat6/2014torngat_mountains_caribou_herd_inuit_knowledge_culture and_values_study.pdf
Zurba, M., Petriello, M.A., Madge, C., McCarney, P., Bishop, B., McBeth, S., Denniston, M., Bodwitch, H., and Bailey, M. 2021. Learning from knowledge co-production research and practice in the twenty-first century: Global lessons and what they mean for collaborative research in Nunatsiavut. Sustainability Science.

https://doi.org/10.1007/s11625-021-00996-x 